\title{
REN C-5312T, but not C-5434T, correlates to increase serum angiotensin I level in angiotensin II receptor blockers-treated hypertensive patients
}

\author{
Mohammad Saifur Rohman', Frastiqa Fahrany², Imama Maslahah3, Widodo4, \\ Mifetika Lukitasari5, Aditya Kurniawan ${ }^{4}$ and Agustina Tri Endharti ${ }^{6}$
}

${ }^{1}$ Department of Cardiology and Vascular Medicine, Faculty of Medicine, University of Brawijaya-Saiful Anwar General Hospital, Malang 65-145, Indonesia; ${ }^{2}$ Biomedical Science, Faculty of Medicine, University of Brawijaya, Malang 65-145, Indonesia; ${ }^{3}$ Brawijaya University Hospital, Malang 65-145, Indonesia; ${ }^{4}$ Biology Department, Faculty of Mathematics and Natural Sciences, University of Brawijaya, Malang 65-145, Indonesia; ${ }^{5}$ Nursing Science, Faculty of Medicine, University of Brawijaya, Malang 65-145, Indonesia; ${ }^{6}$ Parasitology Department, Faculty of Medicine, University of Brawijaya, Malang 65-145, Indonesia.

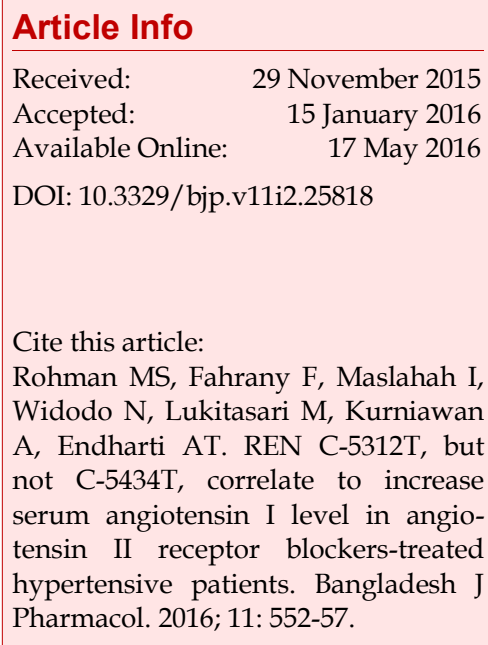

\begin{abstract}
Renin distal enhancer plays a crucial role in regulating renin gene (REN) expression. REN C-5312T enhancer polymorphism increased enhancer activity. REN C-5434T was also identified which supposed to part of enhancer region. Therefore, this study aimed to investigate contribution of both C$5312 \mathrm{~T}$ and $\mathrm{C}-5434 \mathrm{~T}$ to serum angiotensin I in response to angiotensin II receptor blockers (ARB). C-5312T was identified in 46 hypertensive patients by using multiplex polymerase chain reaction (PCR), while C-5434T by using PCR-restiction fragment length of polymorphism (RFLP). Angiotensin I was measured using enzyme linked immunosorbent assay (ELISA). A significant difference of baseline angiotensin I was observed between $-5312 \mathrm{CC}$ and $5312 \mathrm{CT} / \mathrm{TT}(\mathrm{p}=0.038)$ as well as the angiotensin I after 5 months of ARB treatment $(p=0.008)$ in $-5434 \mathrm{CT} / \mathrm{TT}$ population, but not REN C-5434T. In conclusion, $\mathrm{C}-5312 \mathrm{~T}$ resulted in increased mRNA renin level as consequence of higher enhancer activity not only at the baseline but also after 5 months ARB treatment.
\end{abstract}

\section{Introduction}

Renin-angiotensin system (RAS) critically involved in the control of systemic blood pressure (Castrop et al., 2010; Konoshita et al., 2014; Makino et al., 2015). Renin, an aspartyl protease that cleaves angiotensinogen to form the decapeptide angiotensin I (Guang et al., 2012; Santos et al., 2012; Makino et al., 2015). Angiotensin receptor blockers (ARB) is one of RAS inhibitor agents clinically proven to provide many benefits and are widely used in clinical practice (Mancia et al., 2007). If RAS is blocked by the ARB, a feedback mechanism will occur followed by increased renin activity that lead to a compensatory increase in renin release (Cagnoni et al., 2010; Chen et al., 2010). This feedback mechanism was further enhanced the renin level in genetic variant of REN C-5312T hypertensive patients on 5 months of ARB administration, as shown in our previuos study (Rohman et al., 2015).

REN C-5312T was known as part of distal enhancer element (nucleotides -5777 to -5312 ) which has been reported to activate the human renin promoter approximately 60-fold in primary cultures of human chorionic cells (Germain et al., 1998; Fuchs et al., 2002). Inspite of REN C-5312T, REN C-5434T was identified in this 
study, which suppose to affect enhancer activity (Maslahah et al., 2015).

Therefore, this study aimed to investigate contribution of REN C-5312T and C-5434T polymorphism to the change of serum angiotensin I level in ARB-treated hypertensive patients.

\section{Materials and Methods}

\section{Subjects}

Forty six patients with documented hypertension, serum creatinine $<2.5 \mathrm{mg} / \mathrm{dL}$ and good medication adherence were recruited to this study. Then blood sample was taken at sitting position in the morning for detecting polymorphism and measuring serum angiotensin I levels in the beginning of therapy and after receiving ARB for five months.

\section{DNA Extraction}

DNA was extracted from blood samples using gSYNC ${ }^{\mathrm{TM}}$ DNA Isolation Kit (Geneaid) according to the manufacturer instruction. Two hundreds microliters of whole blood and $20 \mu \mathrm{L}$ of proteinase $\mathrm{K}$ were placed into a $1.5 \mathrm{~mL}$ microcentrifuge tube then mixed by pipetting. The mixture was incubated at $60^{\circ} \mathrm{C}$ for $5 \mathrm{~min}$. Cell lysis was achieved by adding $200 \mu \mathrm{L}$ of GSB buffer to the mixture then mixed by shaking vigorously. The cell lysate was incubated at $60^{\circ} \mathrm{C}$ for $5 \mathrm{~min}$. Then, $200 \mu \mathrm{L}$ of absolute ethanol was added to sample lysate and mixed by shaking vigorously for $10 \mathrm{sec}$. All of the mixture (including any insoluble precipitate) was transferred to a GD column which placed in a $2 \mathrm{~mL}$ collection tube and then centrifuged at $14,000 \mathrm{xg}$ for one min. Afterwards, the $2 \mathrm{~mL}$ collection tube containing the flow-through was discarded and transferred the GD column to a new $2 \mathrm{~mL}$ collection tube. Then, $400 \mu \mathrm{L} \mathrm{W1}$ buffer was added to the GD column then centrifuged at $14,000 \mathrm{xg}$ for $30 \mathrm{sec}$. The flow-through was discarded and the GD column was placed back in a new $2 \mathrm{~mL}$ Collection tube. The GD column was washed by adding $600 \mu \mathrm{L}$ wash buffer then centrifuged at 14,000 $\mathrm{g}$ for 30 sec. After centrifuging, the flow-through was discarded and placed back in a new $2 \mathrm{~mL}$ collection tube. To dry the column matrix, the GD column was centrifuged at $14,000 \times \mathrm{g}$ for $3 \mathrm{~min}$. For elution, the dried GD column was transferred to a clean $1.5 \mathrm{~mL}$ microcentrifuge tube and added by $200 \mu \mathrm{L}$ elution buffer and then centrifuged at $14,000 \mathrm{xg}$ for $30 \mathrm{sec}$. The samples were stored frozen at $-20^{\circ} \mathrm{C}$. To make sure the DNA were isolated, the products were viewed in $1.5 \%$ agarose gel stained with ethidium bromide and and photographed under UV illumination.

\section{Detection of C-5312T polymorphism}

Renin gene amplification was assayed by multiplex polymerase chain reaction (PCR) using Takara PCR Thermal Cycler. PCR reaction was carried out in $20 \mu \mathrm{L}$ mixture containing $5 \mu \mathrm{L}$ of $\mathrm{dd} \mathrm{H}_{2} \mathrm{O}, 10 \mu \mathrm{L}$ of PCR Mix (KAPA2G Robust HotStart ReadyMix PCR Kit), $1 \mu \mathrm{L}$ of genomic DNA, $1 \mu \mathrm{L}$ of each primer (sense oligo $5^{\prime}$ CGTAGTGCCATTTTTAGGAAC'-3' and antisense oligo 5'-AACACCAAAGCAGGC-3' with an additional primers was originally designed from the adjacent sequence were the following: sense oligo '5'GCAGTCTCTGTAAGTGCCAC-3' and antisense oligo 5'-CCAAAGCAGGCTTAATCTCA-3'). The cycling conditions consisted of thirty five cycles of the PCR were performed with the following parameters, denaturation at $95^{\circ} \mathrm{C}$ temperature for 30 seconds, annealing at a temperature gradient $48-58^{\circ} \mathrm{C}$ for 30 seconds and extension at $72^{\circ} \mathrm{C}$ for $1 \mathrm{~min}$ followed by a final extension at $72^{\circ} \mathrm{C}$ for $10 \mathrm{~min}$. Then, the products were viewed in $1.5 \%$ agarose gel containing ethidium bromide at 135 voltages for $20 \mathrm{~min}$ and photographed under UV illumination. A 100 bp DNA ladder was run alongside to compare the sizes of fragments. Two fragments (376 bp and $160 \mathrm{bp}$ ) were produced in the presence of $C$ allele homozygote, two fragments (376 bp dan $265 \mathrm{bp}$ ) were produced in the presence of $\mathrm{T}$ allele homozygote, and three fragments $(376 \mathrm{bp}, 265 \mathrm{bp}$, and $160 \mathrm{bp}$ ) were produced in the presence of CT heterozygote (Rohman et al, 2015).

\section{Detection of C-5434T polymorphism}

Genomic DNA samples were identified by means of a PCR, followed by a restriction fragment length of polymorphism (RFLP). PCR reaction was carried out in $20 \mu \mathrm{L}$ mixture containing $7 \mu \mathrm{L}$ of $\mathrm{dd}_{2} \mathrm{O}, 10 \mu \mathrm{L}$ of PCR Mix (KAPA2G Robust HotStart ReadyMix PCR Kit), 1 $\mu \mathrm{L}$ of genomic DNA, $1 \mu \mathrm{L}$ of each primer (forward $5^{\prime}$ CGTAGTGCCATTTTTAGGAAC-3' and reverse 5'TTTCTACTTACCAAATGGCGTC-3'). The cycling conditions compromised an initial denaturation step for $3 \mathrm{~min}$ at $95^{\circ} \mathrm{C}$, followed by 35 cycles consisting of denaturation at $95^{\circ} \mathrm{C}$ for $30 \mathrm{sec}$, annealing at $55^{\circ} \mathrm{C}$ for 30 sec and extension at $72^{\circ} \mathrm{C}$ for $1 \mathrm{~min}$. A final extension step was performed at $72^{\circ} \mathrm{C}$ for one min. The amplified fragment was digested with restriction enzyme (Mae II) at $65^{\circ} \mathrm{C}$ for 5 hours, electrophoresed on a $1.5 \%$ agarose gel stained with ethidium bromide at 100 voltages for $30 \mathrm{~min}$ and photographed under UV illumination at 200 $-400 \mathrm{~nm}$. The presence of C-5434T polymorphism resulted in a loss of the MaeII restriction site (5'-ACGT3') (Maslahah et al, 2015).

\section{Serum Preparation}

The blood samples were collected into covered tube. To separate serum from blood, sample was centrifuged at $3,000 \mathrm{xg}$ for $10 \mathrm{~min}$ at $4^{\circ} \mathrm{C}$. The samples were aliquoted into small tubes and stored $-80^{\circ} \mathrm{C}$. 


\section{Measurement of angiotensin I level}

Enzyme linked-immunosorbent assay (ELISA) was used to measure serum angiotensin I levels at the beginning and after 5 month of ARB treatment. The frozen samples were thawed at room temperature for a few minutes. Before coating antigen, samples were diluted 1:10 with coating buffer and added to the wells. The plate was incubated at $37^{\circ} \mathrm{C}$ for 30 min then placed the plate for incubation at $4^{\circ} \mathrm{C}$ overnight. After incubation, the plate was washed thoroughly with washing solutions $(100 \mu \mathrm{L}$ of PBST $0.2 \%)$ and $100 \mu \mathrm{L}$ of blocking buffer was added. Samples in plate were added $100 \mu \mathrm{L}$ of monoclonal antibody angiotensin I (BGN/KA/22H): $\mathrm{sc}-80682$ and incubated again at $25^{\circ} \mathrm{C}$ for $60 \mathrm{~min}$ and followed by another washing used washing solutions. One hundred microliter of polyclonal antibody (Biotinlabeled affinity purified polyclonal antibody to mouse IgG) was added. The plate was incubated for $60 \mathrm{~min}$ at $25^{\circ} \mathrm{C}$ then washed thoroughly with washing solutions and $100 \mu \mathrm{L}$ of HRP-avidin solution was added. The plate was incubated again at $25^{\circ} \mathrm{C}$ for $60 \mathrm{~min}$ and followed by another washing used washing solutions. Sixty microliters of tetramethylbenzidine (TMB) solution was added and incubated for $30 \mathrm{~min}$ in dark at $25^{\circ} \mathrm{C}$, after which stop solution was then added to each well. Absorbance was recorded immediately on a microplate reader (DIAREADER ELx800 G ELISA) at $450 \mathrm{~nm}$. Serum samples level was calculated from the standard curve and multiplied by the dilution factor.

\section{Statistical analysis}

Baseline characteristics, serum angiotensin I level finding between 2 group were compared by independent t-test. Quantitative variables are expressed as mean \pm SD values. Categorical variables were compared by the Chi-Squared test. For all tests, a value of $p \leq 0.05$ was considered as statistically significant. Statistical analysis was performed under the SPSS 16.0.

\section{Results}

\section{Baseline characteristics}

The baseline characteristics of hypertensive patients between 2 genotype groups; CC and CT/TT of -5312 polymorphism are shown in Table I. Statistical analysis showed that there was no significant differences of baseline characteristics among these two groups. No significant differences also observed regarding the antihypertensive drugs between CC and CT/TT genotype.

\section{Table I}

Baseline characteristics-based on REN C-5312T polymorphism

\begin{tabular}{|c|c|c|c|}
\hline \multirow[t]{2}{*}{ Variable } & \multicolumn{2}{|c|}{ Genetic variant of REN C-5312T } & \multirow[t]{2}{*}{$\mathrm{p}$ value (a) } \\
\hline & $\begin{array}{c}\mathrm{CC} \\
(\mathrm{n}=13)\end{array}$ & $\begin{array}{l}\mathrm{CT} / \mathrm{TT} \\
(\mathrm{n}=33)\end{array}$ & \\
\hline Age (years) & $59 \pm 6.6$ & $58 \pm 8.2$ & NS \\
\hline Gender (M/F) & $8 / 5$ & $15 / 18$ & NS \\
\hline Ureum $(\mathrm{mg} / \mathrm{dL})$ & $25.3 \pm 5.5$ & $27.4 \pm 8.6$ & NS \\
\hline Creatinine $(\mathrm{mg} / \mathrm{dL})$ & $1.1 \pm 0.3$ & $0.9 \pm 0.2$ & NS \\
\hline Cholesterol (mg/dL) & $182.5 \pm 44.3$ & $188.5 \pm 31.3$ & NS \\
\hline Blood glucose $(\mathrm{mg} / \mathrm{dL})$ & $100.2 \pm 10.6$ & $94.3 \pm 9.6$ & NS \\
\hline Body mass index $\left(\mathrm{kg} / \mathrm{m}^{2}\right)$ & $27.2 \pm 4.4$ & $26.6 \pm 3.9$ & NS \\
\hline \multicolumn{4}{|c|}{ Antihypertensive drug combination ( $\mathrm{n}, \%)$ : } \\
\hline ARB & 1 & 6 & NS \\
\hline $\mathrm{ARB}, \mathrm{BB}$ & 3 & 8 & NS \\
\hline $\mathrm{ARB}, \mathrm{CCB}$ & 2 & 6 & NS \\
\hline $\mathrm{ARB}, \mathrm{BB}, \mathrm{CCB}$ & 4 & 3 & NS \\
\hline $\mathrm{ARB}, \mathrm{BB}, \mathrm{HCT}$ & 1 & 4 & NS \\
\hline $\mathrm{ARB}, \mathrm{CCB}, \mathrm{HCT}$ & 2 & 2 & NS \\
\hline $\mathrm{ARB}, \mathrm{BB}, \mathrm{CCB}, \mathrm{HCT}$ & 0 & 4 & NS \\
\hline
\end{tabular}

Values are mean \pm Standart Deviation of the mean; NS indicates not significant if $\mathrm{p}>0.05$, symbol (a) represent a statistical significance if $\mathrm{p}<0.05$; ARB, angiotensin receptor blocker; $\mathrm{BB}$, beta blocker; $\mathrm{CCB}$, calcium channel blocker; HCT, hydrochlorothiazid 
Serum angiotensin I levels between CC and CT/TT genotype of REN-5312 polymorphism

The result performed the analysis of polymorphism not only at C-5312T but also C-5434T of REN. Therefore, 4 groups combination of genotype found considering polymorphism either at -5312 or -5434 . 5312 CC-5434CC genotype observed in $19.5 \%$ of sample, 5312CC$5434 \mathrm{CT} / \mathrm{TT}$ genotype observed in $8.7 \%$ of sample, 5312CT/TT-5434CC genotype observed in $4.4 \%$ of sample and 5312CT/TT-5434CT/TT genotype observed in $67.4 \%$ of sample. Baseline angiotensin I level was measured and compared between -5312CC and $5312 \mathrm{CT} / \mathrm{TT}$ hypertensive patients, either in $-5434 \mathrm{CC}$ or -5434 CT/TT population as shown in Table II and III.

No significant difference of baseline angiotensin level was observed among genotype in -5434 CC population. After 5 months treatment of ARB, serum angiotensin I level also revealed no significant difference among genotypes (Table II). In order to know whether there was significant changes of serum angiotensin I level after treatment, post-treatment baseline was calculated. The difference was not statistically significant.

In hypertensive patients carrying $-5434 \mathrm{CT} / \mathrm{TT}$, a statistical difference was only identified in baseline and post ARB treatment of angiotensin I level, but not in the changes of angiotensin I level as shown in Table III.

\section{Serum angiotensin I levels between CC and CT/TT genotype of REN-5434 polymorphism}

The comparation of serum angiotensin I level among genetic variant of C-5434T REN polymorphism were analyzed, either in hypertensive patients carrying -5312 CC or -5312 CT/TT genotype. Table IV show there was no statistical different of baseline serum angiotensin I level was observed between -5434CC and -5434 CT/TT genotype in $-5312 \mathrm{CC}$ population. After 5 months treatment of $\mathrm{ARB}$, angiotensin I level also revealed no significant difference among genotypes as well as the change of angiotensin I level (Table IV).

In addition, no statistical difference was found in hypertensive patients carrying $-5312 \mathrm{CT} / \mathrm{TT}$, not only in baseline serum angiotensin I level but also after 5 months of ARB treatment and the change of angiotensin I between $-5434 \mathrm{CC}$ and $-5434 \mathrm{CT} / \mathrm{TT}$ genotype (Table $\mathrm{V})$.

\section{Discussion}

Our present study represents the genetic investigation of a possible contribution of REN C-5312T and C-5434T polymorphism to the change of serum angiotensin I level in treated angiotensin II receptor blocker (ARB) Indonesian hypertensive patients. This study has shown that $-5312 \mathrm{CT} / \mathrm{TT}$ polymorphism resulted in
Table II

Serum angiotensin I level among genetic variant of REN C-5312T in -5434 CC population

\begin{tabular}{|lccc|}
\hline Variable & \multicolumn{2}{c}{-5434 CC } & p value \\
\hline Variable & $\begin{array}{c}-5312 \mathrm{CC} \\
(\mathrm{n}=9)\end{array}$ & $\begin{array}{c}-5312 \mathrm{CT} / \mathrm{TT} \\
(\mathrm{n}=2)\end{array}$ & \\
& $\begin{array}{l}40.2 \pm 4.3 \\
\text { Ang 1 pre }\end{array}$ & $46.9 \pm 7.1$ & NS \\
Ang 1 post & $41.7 \pm 4.2$ & $44.2 \pm 5.5$ & NS \\
$\Delta$ Ang 1 & $1.5 \pm 3.9$ & $-2.7 \pm 1.6$ & NS \\
\hline
\end{tabular}

Data are mean $\pm S D$; NS indicates not significant if $p>0.05$, symbol (a) represent a statistical significance if $\mathrm{p}<0.05$

\section{Table III}

Serum angiotensin I level among genetic variant of REN C-5312T in -5434 CT/TT population

\begin{tabular}{lccc} 
Variable & \multicolumn{2}{c}{$-5434 \mathrm{CT} / \mathrm{TT}$} & $\mathrm{p}$ value \\
\cline { 2 - 3 } & $\begin{array}{c}-5312 \mathrm{CC} \\
(\mathrm{n}=4)\end{array}$ & $\begin{array}{c}-5312 \mathrm{CT} / \mathrm{TT} \\
(\mathrm{n}=31)\end{array}$ & \\
Ang 1 pre & $37.2 \pm 2.7$ & $41.5 \pm 4.9$ & $<0.05^{\mathrm{a}}$ \\
Ang 1 post & $37.4 \pm 2.6$ & $43.2 \pm 5.4$ & $<0.05^{\mathrm{a}}$ \\
$\Delta$ Ang 1 & $0.2 \pm 1.1$ & $1.7 \pm 4.6$ & NS \\
\hline
\end{tabular}

Values are mean $\pm S D$; NS indicates not significant if $p>0.05$, symbol (a) represent a statistical significance if $\mathrm{p}<0.05$

\begin{tabular}{|c|c|c|c|}
\hline \multicolumn{4}{|c|}{ Table IV } \\
\hline \multicolumn{4}{|c|}{$\begin{array}{l}\text { Serum angiotensin I level among genetic variant of } \\
\text { C-5434T in } 5312 \mathrm{CC} \text { population }\end{array}$} \\
\hline \multirow[t]{2}{*}{ Variable } & \multicolumn{2}{|c|}{$-5312 \mathrm{CC}$} & $\mathrm{p}$ value \\
\hline & $\begin{array}{c}-5434 \text { CC } \\
(\mathrm{n}=9)\end{array}$ & $\begin{array}{l}-5434 \text { CT } / \mathrm{TT} \\
(\mathrm{n}=4)\end{array}$ & \\
\hline Ang 1 pre & $40.2 \pm 4.3$ & $37.1 \pm 2.7$ & NS \\
\hline Ang 1 post & $41.7 \pm 4.2$ & $37.4 \pm 2.6$ & NS \\
\hline$\Delta$ Ang 1 & $1.5 \pm 3.9$ & $0.2 \pm 1.1$ & NS \\
\hline
\end{tabular}

Values are mean $\pm S D$; NS indicates not significant if $p>0.05$, symbol (a) represent a statistical significance if $\mathrm{p}<0.05$

\section{Table V}

\begin{tabular}{lccc|}
\multicolumn{3}{c}{$\begin{array}{c}\text { Serum angiotensin I level among genetic variant of } \\
\text { C-5434T in 5312 CT/TT population }\end{array}$} \\
\cline { 2 - 3 } Variable & \multicolumn{2}{c}{-5312 CT/TT } & p value \\
\cline { 2 - 3 } & $\begin{array}{c}-5434 \mathrm{CC} \\
(\mathrm{n}=2)\end{array}$ & $\begin{array}{c}-5434 \mathrm{CT} / \mathrm{TT} \\
(\mathrm{n}=31)\end{array}$ & \\
Ang 1 pre & $46.9 \pm 7.1$ & $41.5 \pm 4.9$ & NS \\
Ang 1 post & $44.2 \pm 5.5$ & $43.2 \pm 5.4$ & NS \\
$\Delta$ Ang 1 & $-2.7 \pm 1.6$ & $1.7 \pm 4.6$ & NS \\
\hline
\end{tabular}

Values are mean \pm SD; NS indicates not significant if $p>0.05$, symbol (a) represent a statistical significance if $\mathrm{p}<0.05$

higher angiotensin I level both at baseline and after 5 months ARB treatment compared to -5312 CC hyper- 
tensive patients. However, no angiotensin I level changes observed in C-5434T polymorphism at the baseline and after treatment. At the baseline higher level of angiotensin I in -5312 CT/TT individual might be related to increased renin level in this population. Our previous study have shown that a change from $\mathrm{T}$ to $\mathrm{C}$ causing displacement of Sp1 binding site from center to down-stream of GC rich sequence, and resulted in Sp1 loss of contact with bases -5312 , which in turn failure of renin gene stimulating transcription by Sp1 in -5312CC individu (Lukitasari et al., 2011). Coversely, Fuchs et al. (2002) showing 45\% greater rates of REN transcription in the presence of a $-5312 \mathrm{~T}$ allele rather than a $-5312 \mathrm{C}$ allele. So, REN C-5312T polymorphism resulted in increased renin protein level and finally increased angiotensin I as shown by this study.

Previous study showed that there was a significant elevation of serum angiotensin I levels among hypertensive patients with REN C-5312T after receiving valsartan (Konoshita et al., 2009), even if they did not investigate REN C-5434T polymorphism. Angiotensin II receptor blocker (ARB) treatment are associated with feedback loop mechanism that increases renin activity, as loss of stimulation of AT1 receptors on juxtaglomerular cells in the kidney leads to a compensatory increase in renin release. The whole RAAS is, therefore, up-regulated although AT1 receptor -mediated effects of the effector molecule angiotensin II are blocked (Cagnoni et al., 2010). In hypertensive ARB treated patient, REN C-5312T further renin mRNA accumulated in addition to increase renin activity as consequence of feedback loop mechanism. Therefore angiotensin I product also significantly detected higher in REN C-5312T.

\section{Conclusion}

REN C-5312T, but not REN C-5434T, polymorphism resulted in increased mRNA renin level as consequence of higher enhancer activity not only at the baseline but also after 5 months ARB treatment.

\section{Ethical Issue}

The study was approved by local committee on medical research ethics. Written informed consent was obtained from all study participant.

\section{Conflict of Interest}

No potential conflict of interest relevant to this paper was reported (see the link for documents in HTML format file).

\section{Acknowledgement}

We thank the dedicated hypertension research team who traced participants and collected the data. This paper was supported by Saiful Anwar General Hospital Malang, Indonesia.

\section{References}

Cagnoni F, Njwe CAN, Zaninelli A, Ricci AR, Dafra D, D'Ospina A, Preti P, Destro M. Blocking RAAS at different levels: An update on the use of the direct renin inhibitors alone and in combination. Vasc Health Risk Manag. 2010; 6: 549-59.

Castrop H, Hocherl K, Kurtz A, Schweda F, Todorov V, Wagner C. Physiology of kidney renin. Physiol Rev. 2010; 90: 607-73.

Chen L, Soomi K, Eisner C, Oppermann M, Huang Y, Mizel D, Li L, Chen M, Lopez MLS, Weinstein LS, Gomez RA, Schnermann J, Briggs JP. Stimulation of renin secretion by angiotensin II blockade is Gsa-dependent. J Am Soc Nephrol. 2010; 21: 986-92.

Fuchs S, Philippe, J, Germain S, Mathieu F, Jeunemaitre X, Corvol P, Pinet F. Functionality of two new polymorphisms in the human renin gene enhancer region. J Hypertens. 2002; 20: 2391-98.

Germain S, Bonnet F, Philippe J, Fuchs S, Corvol P, Pinet F. A novel distal enhancer confers chorionic expression on the humanrenin gene. J Biol Chem. 1998; 273: 25292-300.

Guang C, Philips RD, Jiang B, Milani F. Three key proteasesangiotensin-I-convertingenzyme (ACE), ACE2 and reninwithin and beyondthe renin-angiotensin system. Arch Cardiovasc Dis. 2012; 105: 373-85.

Konoshita T, Kato N, Fuchs S.,Mizuno S, Aoyama C, Motomura M, Makino M, Wakahara S, Inoki I, Miyamori I, Pinet F. Genetic variant of the renin-angiotensin system and diabetes influences blood pressure response to angiotensin receptor blockers. Diabetes Care. 2009; 32: 1485-90.

Konoshita T, Nakaya T, Sakai A, Yamada M, Ichikawa M, Sato S, Imagawa M, Fujii M, Yamamoto K, Makino Y, Arakawa K, Suzuki J, Ishizuka T. Determinants of plasma renin activity: Role of a human renin gene variant as a genetic factor. Medicine. 2014; 93: e354.

Lukitasari M, Rohman MS, Hendrawan D. Achievement of blood pressure target with angiotensin blockage based therapy in outpatient clinic. 5th scientific meeting of Indonesian Society of Hypertension Abstract Book, 2011.

Makino Y, Konoshita T, Omori A, Maegawa N, Nakaya T, Ichikawa M, Yamamoto K, Wakahara S, Ishizuka T, Onoe T, Nakamura $H$. A genetic variant in the distal enhancer region of the human renin gene affects renin expression. PLoS ONE. 2015; 10: e0137469.

Mancia G, De Backer G, Dominiczak A, Cifkova, Fagard R, Germano G, Grassi G, Heagerty AM, Kjeldsen SE, Laurent S, 
hypertension: The task force for the management of arterial hypertension of the European Society of Hyper-tension (ESH) and of the European Society of Cardiology (ESC). J Hypertens. 2007; 25: 1105-87.

Maslahah I, Rohman MS, Widodo N, Endharti AT, Utomo D. Genetic variant of C-5434T REN enhancer on serum renin levels and binding pattern of signal transducers and activators transcription 3. Int J Hypertens. 2015, 2015.
Rohman MS, Satiti IAD, Widodo N, Lukitasari M, Sujuti H. Genetic variants of C-5312T REN increased renin levels and diastolic blood pressure response to angiotensin receptor blockers. Int J Hypertens. 2015, 2015.

Santos PCJL, Krieger JE, Pereira AC. Renin-angiotensin system, hypertension, and chronic kidney disease: Pharmacogenetic implications. J Pharmacol Sci. 2012; 120: 77-88. 


\section{Your feedback about this paper}

1. Number of times you have read this paper 0

2. Quality of paper

$\bigcirc$ Excellent $\bigcirc$ Good $\bigcirc$ Moderate $\bigcirc$ Not good

3. Your comments

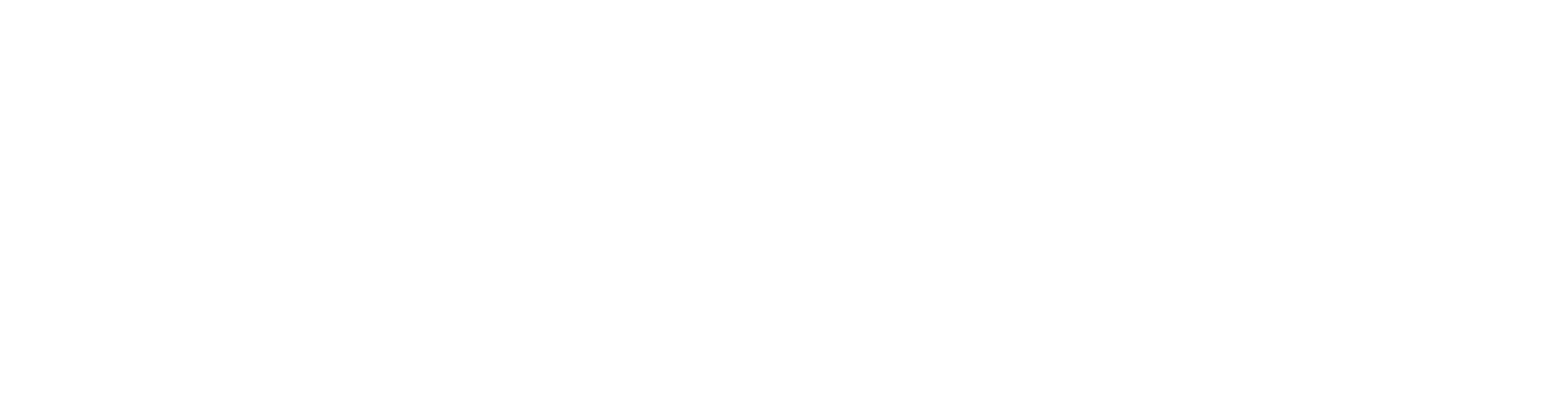

